\title{
RELATOS Y RITUALIDADES EN TORNO AL LAGO-MUJER. PRÁCTICAS FESTIVAS Y NARRATIVAS EN ZIRAHUÉN
}

\section{BERENICE ARACELI GRANADOS VÁZQUEZ \\ ESCUELA NACIONAL DE ESTUDIOS SUPERIORES \\ UNIDAD MORELIA, UNAM}

bereniceagv@yahoo.com.mx

Article received on 05.02.2014

Accepted on 25.07.2014

\begin{abstract}
RESUMEN
En el lago de Zirahuén (Michoacán, México) existe una ritualidad que subyace a las prácticas narrativas y festivas de los habitantes de los pueblos ribereños. Este artículo combina materiales obtenidos en trabajo de campo y fuentes etnográficas e históricas prehispánicas y coloniales, para aproximarse al complejo cultural mujer-lago a partir de sus distintos niveles de significación: como un elemento geográfico y como una construcción mítica que se materializa en dos figuras, la jícara y la sirena.

PALABRAS CLAVE

Sirena, lago, jícara, Zirahuén, ritual, narrativa tradicional, fiesta de la Santa Cruz, Corpus Christi, Cueravaperi, Xaratanga.
\end{abstract}

TALES AND RITUALS OF THE WOMAN LAKE. FESTIVITIES AND NARRATIVES IN ZIRAHUEN

\section{ABSTRACT}

The lake of Zirahuen (Michoacan, Mexico) is home to rituals that underlie the narratives and festivities of the inhabitants of the coastal villages. This paper combines fieldwork materials with ethnographic and historical sources to explain the different meanings of the cultural complex woman-lake, which may be understood as a geographical element and as a mythical construction embodied by two figures, the jícara (gourd) and the siren.

\section{KEYWORDS}

Siren, lake, gourd, Zirahuen, ritual, traditional narrative, Festival of the Crosses, Corpus Christi, Cueravaperi, Xaratanga. 


\section{INTRODUCCIÓN}

La sirena con su forma habitual (hermosa mujer con cola de pez) es parte de la tradición oral del pueblo y las rancherías que rodean el lago de Zirahuén. Ubicado en el estado de Michoacán, es el lago más profundo y de mayor altitud de la zona centro-occidente de México. Forma parte de un conjunto volcánico que lo originó cuando sus lavas interrumpieron el paso del río La Palma. Por esta razón, el lago está rodeado por una cadena de cerros, de tal forma que el sistema lacustre con sus elevaciones y cuevas constituye un paisaje curioso que tiende a ser antropomorfizado. Tal como lo narró el señor Gabino Calvillo, vecino del pueblo de Zirahuén:

Mire, no me lo va a creer, pero allá en el cerro ese, en el cerrito que está aquí de Zirahuén, en la mera punta se ve la mujer: los pies, los brazos, las manos. Allá se ve a la mujer bien clarita, vestidos, sus manos pa los lados, los pies, todo se ve. Los pies son aquí. Allá hasta la punta. Y allá el vestido es el llano de Copándaro. La cabeza es allá por donde está El Rincón, de aquel lado. Es una mujer. Allá sí se ve bien la mujer, clarito, allá de aquel lado.

En este trabajo ensayaré una forma de acercamiento, a través de los relatos y ritualidades. Pretendo aproximarme al complejo cultural ${ }^{1}$ lago Zirahuén a partir de sus distintos niveles de significación: como un elemento geográfico que constituye el sustento principal de los pobladores ribereños y como una construcción mítica en la que el lago se materializa en dos figuras: la jícara y la sirena. Este complejo recreado a partir del lago pone de manifiesto la relación, mediada por una visión de mundo, que establecen los ribereños con el recurso natural desde antaño. Ante la multitud de expresiones culturales que tienen una vinculación con el lago, considero que en Zirahuén existe una ritualidad implícita que subyace a las prácticas narrativas y festivas de los ribereños, situación que demostraré a la luz de un breve rastreo histórico y etnográfico de la zona.

Los relatos aquí citados fueron recopilados en trabajo de campo durante tres estancias en Zirahuén, en enero, mayo y junio de 2013. Este trabajo forma parte de mi investigación doctoral "Deseo y muerte: entidades femeninas en las tradiciones mesoamericanas”. Las transcripciones que aquí presento conservan rasgos de oralidad, no omito muletillas ni repeticiones, y fueron

\footnotetext{
${ }^{1}$ Entendido aquí como un conjunto de manifestaciones culturales elaboradas por los pueblos ribereños, a través de las cuales reconstruyen social y simbólicamente el lago.
} 
extraídas de entrevistas abiertas realizadas a las personas que aparecen en el índice de narradores al final ${ }^{2}$.

\section{CARACTERÍSTICAS GEOLÓGICAS DEL LAGO DE ZIRAHUÉN}

Pese a lo que dicen las guías turísticas, la palabra Zirahuén no significa "espejo de los dioses”, sino que podría remitir a un antiguo verbo purépecha "sirauani”, que Maturino Gilberti traduce como "humear o salir humo" (1997: 146). Según los pobladores ribereños, el agua del lago está caliente por las mañanas, tanto que puede apreciarse el vapor que emana de ella. "El lago humea", dicen3.

El lago de Zirahuén tiene una superficie de forma pentagonal de 9,7 kilómetros cuadrados; actualmente su profundidad máxima es de cuarenta metros y su temperatura oscila entre los dieciséis y los veintidós grados centígrados. Se encuentra en el campo volcánico Michoacán-Guanajuato, en una cuenca rodeada por depósitos volcánicos, limitada al norte por la cuenca del río Lerma y al sur por la del río Balsas. El lago es producto de múltiples erupciones provenientes del conjunto volcánico La Magueyera, hacia el occidente, así como del acomodamiento de placas tectónicas. Según estudios de sedimentación geológica la formación del lago tiene más de 17.000 años de antigüedad (Vázquez et al. 2010: 327).

\footnotetext{
${ }^{2}$ Para mayor información sobre la metodología utilizada en trabajo de campo véase Granados, "Notas y reflexiones sobre la recopilación y el tratamiento de materiales de literatura oral", en Revista de Literatura Populares, XII-1 (2012): 289-318.

3 Don Gabino Calvillo insistió en que el fenómeno puede ser observado desde los cerros que rodean el lago.
} 


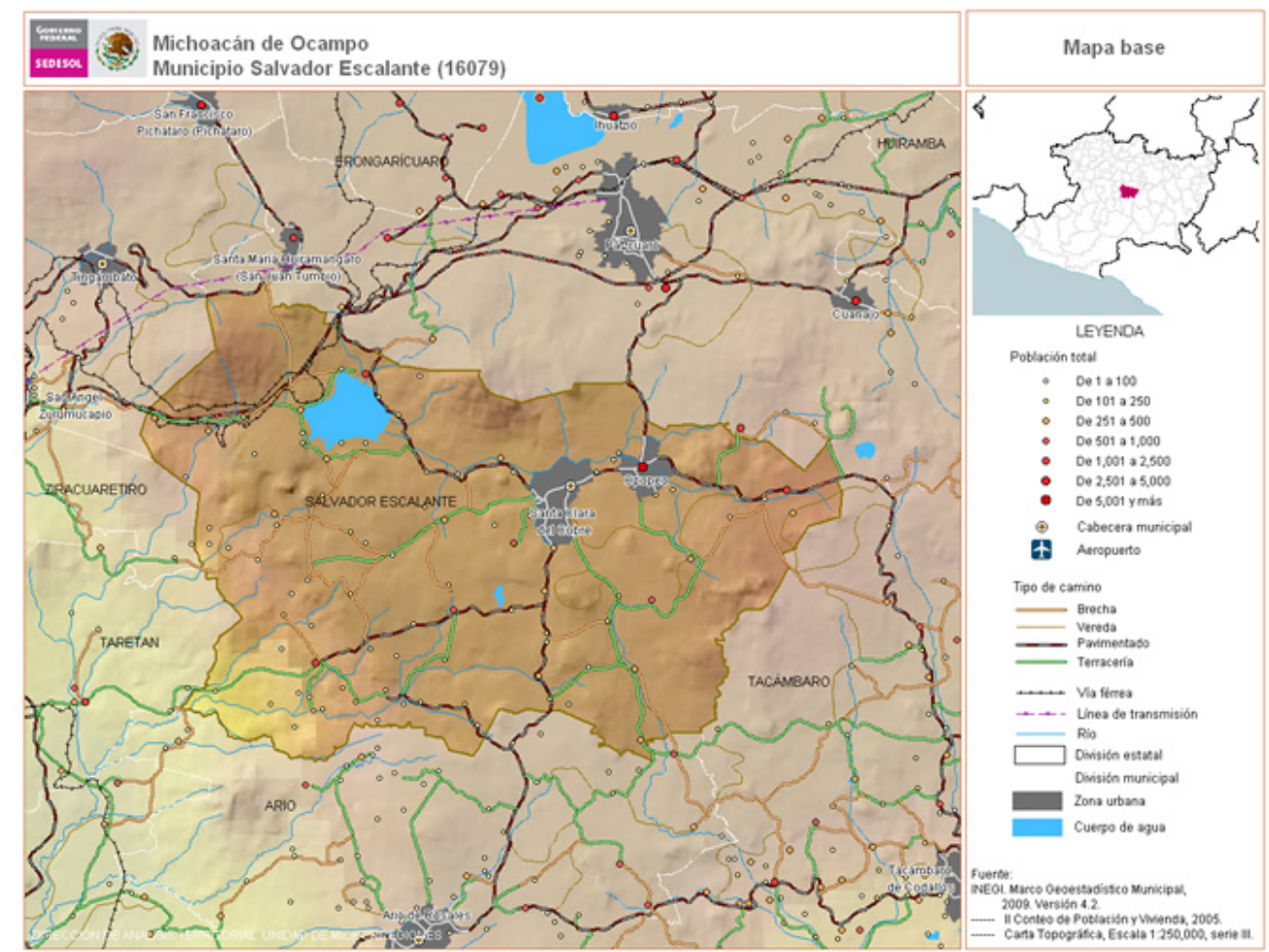

Fig. 1. Lago de Zirahuén en el municipio de Salvador Escalante (SEDESOL).

\section{ASENTAMIENTOS HUMANOS}

Alrededor del lago hay cuatro asentamientos humanos: Zirahuén, Tembúcharo, Agua Verde y Copándaro, que forman parte de la jurisdicción del municipio de Salvador Escalante. La población en la zona es de 2.942 habitantes ${ }^{4}$. El pueblo se localiza en una planicie en la parte norte del lago y está rodeado por cerros cubiertos de bosques de coníferas y encinares, aunque gran parte del territorio ha sido deforestada para utilizar las maderas en la construcción y, sobre todo, para la explotación de suelos agrícolas. Actualmente se destinan grandes extensiones de tierra para las plantaciones aguacateras.

Existen dos caminos para llegar a Zirahuén: el de la desviación de la carretera Pátzcuaro-Uruapan y un camino adoquinado de siete kilómetros que lo comunica con Santa Clara del Cobre, cabecera municipal. La traza del pueblo incluye treinta y dos manzanas o cuadras organizadas en cuatro cuarteles o agrupaciones barriales. Las casas tienen muros de adobe pintados

4 Datos de INEGI, Censo de Población y Vivienda 2010. 
de blanco y techos de teja de barro. La mayoría de las calles son de tierra y algunas están pavimentadas o empedradas.

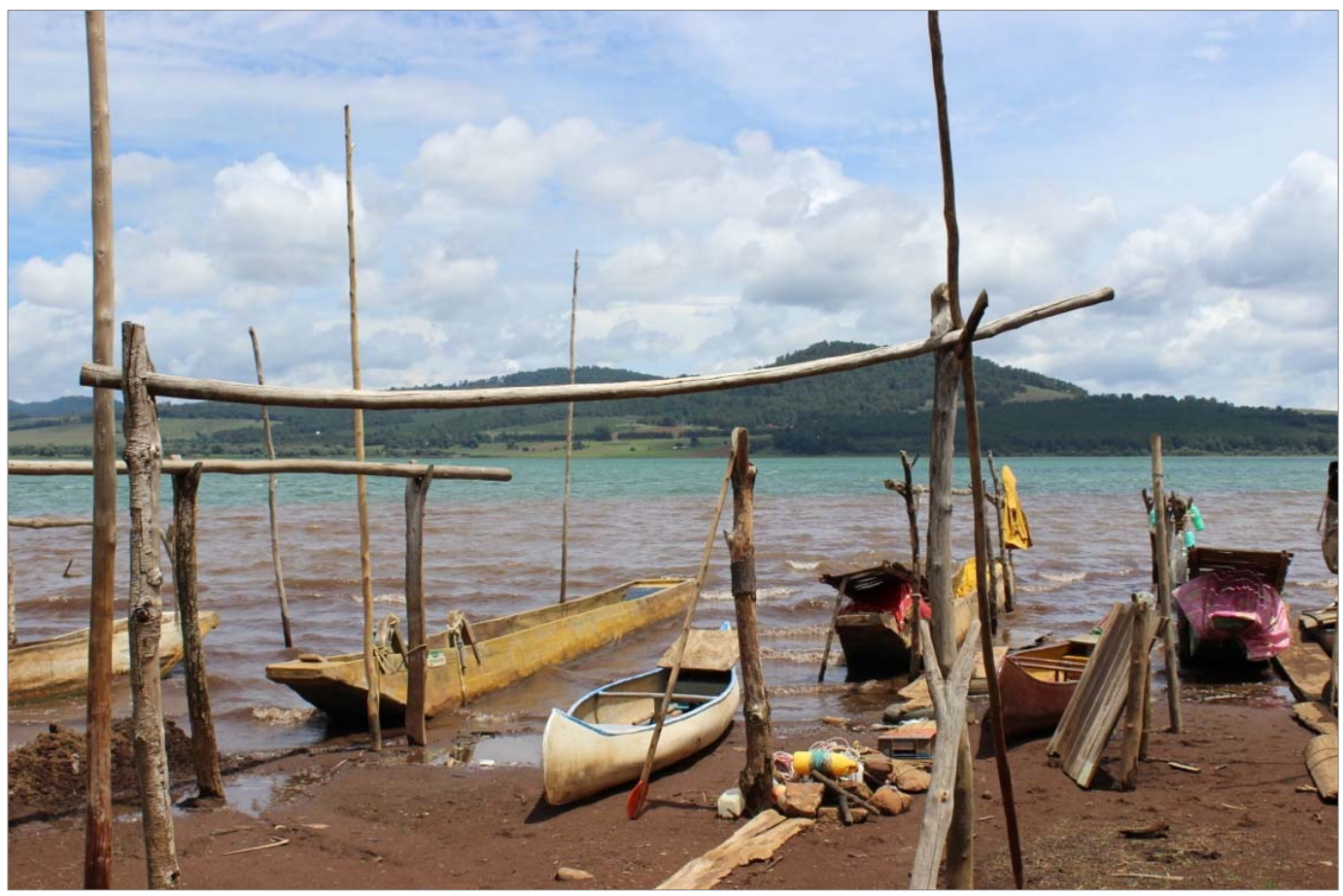

Fig. 2. Noroeste del lago de Zirahuén, herramientas de pescadores (Granados, junio de 2013).

El pueblo de Zirahuén cuenta con dos muelles principales para acceder al lago: uno privado, que se ubica en las cabañas turísticas de la familia Arreola, y uno público, situado en la parte central y donde se puede abordar una lancha grande propiedad de la Unión de Pescadores. Este muelle está rodeado por algunos restaurantes que pertenecen a familias del pueblo, algunos con salientes sostenidos por pilotes en el agua. Las casas situadas alrededor del lago tienen pequeños muelles donde las mujeres acostumbran a lavar la ropa y los hombres mantienen sus pangas, cuelgan sus redes y sus instrumentos de pesca. En estos lugares suelen bañarse por las tardes durante el verano, cuando el clima es templado y no hace el característico frío de la zona. Las actividades económicas de los pueblos ribereños son la agricultura, el turismo, el comercio y la pesca. Esta última es desarrollada cotidianamente por gran parte de la población, aunque se considera que solo unas cuantas familias tienen como oficio el de pescador: "En Zirahuén, no todos los que pescan se definen como pescadores. Se conoce como tales, como verdaderos pescadores, a los que pescan con chinchorro, una red grande y pesada que debe ser tendida y jalada por varias personas. De las artes que se utilizan, el chinchorro es el más costoso" (Cuello et al. 1986: 182). 
Según los estudios de sedimentación geológica practicados al lago de Zirahuén, la actividad del hombre en la zona data de hace 3000 años aproximadamente 5 , aunque se intensifica hacia el 1100 d. C., al final del período clásico mesoamericano. El pueblo de Zirahuén es mencionado en la Relación de Michoacán, documento del siglo XVI donde se registran las historias y mitos purépecha del linaje chichimeca Uacúsecha, conquistador de los pueblos ribereños del lago de Pátzcuaro que extendió su dominio en la zona occidental de México en el posclásico mesoamericano.

En uno de los pasajes se narra cómo el señor de Siraueny, Quarácuri, participa en un plan para capturar a Nacá (sacerdote de Zurumban, el señor de Tariaran), cuando este pretende hacer una guerra al héroe Tariácuri. Al final, es en el pueblo de Zirahuén donde se cocina la carne del sacerdote para enviársela a su señor como venganza ${ }^{6}$.

El arqueólogo Salvador Pulido en un informe técnico del INAH de 1997 documentó en la zona cuatro sitios arqueológicos del posclásico tardío (12001537): Cerro Colorado 1, Copándaro (dos estructuras de dos a cinco metros de altura, plataformas y terrazas localizadas en una extensión de una hectárea), Cerro Colorado 2 (un montículo de menos de dos metros de altura) y El Pinito (un montículo de dos a cinco metros de altura) (cf. Espejel 2000).

Por tal razón, podemos decir que el lago de Zirahuén ha tenido una intensa vida cultural durante los últimos novecientos años. Si tomamos en cuenta que la Relación de Michoacán describe a los pueblos lacustres como pueblos de pescadores, podemos suponer que la actividad de la pesca tiene también una larga tradición en la zona.

5 "La presencia de granos de polen de maíz en estas secuencias sedimentarias indica la existencia de actividades agrícolas en la cuenca al menos desde ca. 3000 años cal AP, y por lo tanto el impacto humano debió ser también un factor importante en los cambios ambientales inferidos" (Vázquez et al. 2010: 341).

6 "Y partióse Nacá y estaba un pueblo en el camino llamado Syráueni y era señor en él uno llamado Quarácuri, y pasó por su puerta Nacá, y díjole Quarácuri: ‘Seáis bienvenido, hermano. Ven acá y comerás un poco, pues que veniste a pasar a mi casa, y traes hambre. Seas bienvenido, señor. Cierto que has de comer'. Y sacáronle de comer y también trujeron de comer a Quarácuri y comieron y laváronse las manos y dijo Nacá: 'Ya he comido, hermano, quiérome aparejar para ir'. Díjole Quarícuri: ‘¿Dónde vas, hermano? Pues yo que soy viejo, ¿no sabré algo dello?’. Respondió Nacá: ‘¿Por qué no lo has de saber? Sí, sabrás, cierto. Yo voy a la laguna y desde allí llamaré a los de Curýnguaro y voy a hacer gente, que habemos de destruir a Taríacuri'. Dijo Quarácuri: 'Sí, sí, bien me parece, señor. ¿Yo lo sabré cuando fuéredes?’. Díjole Nacá: ‘Pues hermano, ¿no irás comigo con tu gente?’. Respondió Quarácuri: ‘¿Por qué no, señor? Es si no muy cerca donde dices, porque aquí luego es. Y yo cogeré los despojos de lo que les haré dejar, aunque sean piedras de moler o algunas alhajas'. Dijo Nacá: ‘Así será, hermano, que nuestros dioses les harán dejar despojos”' (Alcalá 200o: 380). 
En la época colonial, Zirahuén era conocido como "El común de los indios de Zirahuén”. Formaba parte de los 125 curatos que pertenecían al Obispado de Michoacán y era administrado por un cura secular (Moreno 1776: 3)7. Podemos saber por los Autos de Zirahuén de 1733 -documento en el que el cura local promueve una acción legal en nombre de los naturales del pueblo para proteger las tierras contra personas ajenas - que el pueblo estaba bajo el régimen de propiedad comunal:

Las tierras que por derecho pertenecían a los indios abarcaban una superficie equivalente a poco más de 20 mil hectáreas. Una parte correspondía a tierras amparadas por la Cédula Real de 1607; otra, a la tierra que les fue otorgada por los caciques Juan Carrillo de Guzmán y Ana de Castilleja, a fines del siglo XVII, para costear con su producto la celebración de "El descendimiento de Cristo". Completaba la superficie una porción de tierra donada a los indios por un tal Blas Rius de Gauna, quien las había comprado a los caciques mencionados (Cuello et al. 1986: 165).

Hacia 1800 las haciendas de la región despojaron a los campesinos de grandes extensiones de tierra; los zirahuenses conservaron una mínima porción de tierra comunal que, aunque les permitía conservar sus raíces históricas, resultaba insuficiente para el sostén y la alimentación de sus familias. Muchos de los zirahuenses migraron hacia Tierra Caliente para trabajar en los trapiches (Cuello et al. 1986: 166). A pesar de que no participaron en la Revolución mexicana, solicitaron al gobierno obregonista la restitución de sus tierras, pero como no contaron con la documentación suficiente para probar el despojo, su acción legal no prosperó; solo consiguieron una dotación de 1.200 hectáreas de "terrenos en general" en 1923. Este fue el inicio de una serie de acciones legales y luchas por la tierra en la que quedaba manifiesta la situación de los pobladores lacustres: el despojo de los terratenientes era y es auspiciado por los distintos niveles de autoridad. El conflicto por la tierra terminó por dividirlos en tres bandos: una comunidad indígena, una comunidad agraria, ambas con tierras para su explotación, y una unión de pescadores, que son aquellos que no las poseen (Cuello 1986: 165).

\footnotetext{
7 "Tiene famosas Lagunas, y entre ellas son de mucho nombre la de Chapala; la de Michuacan, q[u]e hoy se llama Patzcualo [sic.]; y la de Yuririapundaro, por los abundantes, y delicados pezes $\mathrm{q}[\mathrm{u}] \mathrm{e}$ hai en ellas: $\mathrm{y}$ tiene otras de menos consideracion, como las de Tzacapu, Tarimbaro, Cuitzeo, y Zirahuen” (Moreno 1776: 2).
} 
Los pobladores ribereños de Zirahuén tienen un claro sustrato indígena, descienden de aquellos tarascos que habitaban el mismo espacio antes de la conquista. Sin embargo, ante tal historia de migración y conflicto, ya no hablan el purépecha. A la luz de un breve rastreo histórico del lago Zirahuén sabemos que en la época prehispánica formaba parte del territorio tarasco y aunque contamos con poca información sobre la cosmovisión de los purépecha a la llegada de los españoles (comparada con la zona del Altiplano central), histórica y antropológicamente la zona occidente se considera parte del área cultural denominada Mesoamérica. Con todo y los procesos de conquista y asimilación en la zona lacustre purépecha, así como en el resto de Mesoamérica, se han preservado ideas fundamentales relativas a la estructura y organización del cosmos.

\section{VIDA CEREMONIAL: LOS SITIOS DEL AGUA}

El pueblo de Zirahuén tiene una iglesia franciscana del siglo XVI con amplios muros de piedra y adobe y una nave central que presenta una bóveda de madera ensamblada. Está dedicada al Señor del Perdón, santo patrono del pueblo. La escultura que lo representa es de raíz de tejocote y tiene, como en otros pueblos purépecha, una réplica de madera y de pasta de caña que sale a distintas procesiones ${ }^{8}$. Las celebraciones del Señor del Perdón no tienen un día establecido, varían en toda la zona. En Zirahuén la fiesta de esta imagen se celebra el 3 de mayo9. Forma parte del ciclo ritual, que también incluye el 2 de febrero (Candelaria), el 24 de junio (San Juan), el 31 de octubre (Virgen del Rosario), el Carnaval, la Cuaresma y el Corpus Christi (de fecha móvil según el calendario oficial católico que lo determina a partir del equinoccio de primavera), el 1 y 2 de noviembre (Todos los Santos), el 12 de diciembre (Virgen de Guadalupe) y el 24 de diciembre (Navidad).

Las fiestas en Zirahuén, al igual que en otros sitios, están íntimamente relacionadas con el calendario agrícola, dividido en dos fases que dan sentido a los rituales celebrados: la temporada de secas (de fines de octubre a mediados de junio) y la temporada de lluvias (de fines de junio a mediados de octubre). Los zirahuenses consideran que son dos las fiestas más importantes: la del Señor del Perdón y el Corpus Christi. En ellas, a diferencia de las otras

\footnotetext{
${ }^{8}$ En Ihuatzio, pueblo ribereño del lago de Pátzcuaro, la réplica del santo permanece todo el año en la casa de los cargueros; en este sitio se le conoce como vicario.

9 En los pueblos de la región occidente se celebra en distintas fechas, por ejemplo en Villa Morelos, Michoacán se celebra el 1 de enero, en Tuxpan, Jalisco se celebra del 14 al 24 de mayo, en Zapoltic, Jalisco, el jueves de ascensión.
} 
fiestas que son más pequeñas, participa el pueblo entero. A pesar de los viejos conflictos de tierra mencionados líneas arriba, se organizan los cuarteles y los oficios y se distribuyen tareas específicas.

La fecha de la fiesta del Señor del Perdón coincide en Zirahuén con una de las fiestas más emblemáticas de la religión católica celebrada entre los pueblos de tradición mesoamericana: el día de la Santa Cruz, una fiesta que fue resignificada por los pueblos de origen prehispánico, y que ahora implica ciertos actos rituales encaminados a la propiciación de lluvia. Se acostumbra, por ejemplo, a poner una cruz sobre los cerros, pues en la cosmovisión mesoamericana los cerros albergan las lluvias y las semillas que alimentarán a los hombres, son la casa de las entidades acuáticas que se encargan de proveer a la tierra y a los hombres de alimento:

Los cerros guardan en sus entrañas las aguas que deben circular de nuevo para que se reinicie el ciclo de las lluvias. La importancia de los cerros también varía con su altura y la profundidad de los pozos que dan acceso a su interior. Se aprecia el prestigio de un sitio por el área concéntrica de los pueblos que acuden a su cumbre en el periodo de fin de abril hasta mediados de mayo [...]. Los cerros tienen aperturas que dan sobre las aguas del mundo subterráneo. Es en estas oquedades que se forman las neblinas. Las aguas detenidas durante la época de sequía deben fluir al principio de la época de lluvia para que alcancen el mar, donde han de elevarse de nuevo para llegar a sus cúspides y repartirse en sus alrededores (Neff Nuixa 2008: 327).

No sorprende por ello que el día del Señor del Perdón se lleve a cabo una celebración en dos espacios distintos: el templo en el centro del pueblo y el cerro. La celebración del Señor del Perdón comienza con varios días de antelación. El día 1 de mayo se acude al Cerrito Colorado, donde en su parte más alta hay una cruz que se adorna con listones denominados cuelgas. Para esta labor se nombra a un "cuelguero”, tal como lo narró Salud Padilla: “Al lado de arriba hay una cruz, y a esa cruz le hacen su fiesta porque son cuelgueros y quitan la cuelga y cada mes [sic]... el día primero de mayo, le ponen su cuelga". Esta cuelga se acompaña por ofrendas florales y copal. Los demás días las actividades se desarrollan en el pueblo; durante la semana llegan procesiones de muy distintos lugares, acompañadas de cohetes y banderillas de papel, para recibir la bendición del santo patrono. El día 3 se le cantan las mañanitas y se celebra una larga homilía en la que se bendice a los nuevos monaguillos. Solo este día el Cristo sale del altar y recorre, en los hombros de los habitantes, las calles de Zirahuén "para que bendiga a sus hijos y restablezca el orden entre el bien y el mal” (Alcalá 2008). Al terminar la procesión se realiza la tradicional danza de moros y cristianos y la de 
mojigangas, y por la noche se quema un castillo y algunos otros juegos pirotécnicos. La fiesta se intercala con jaripeos y bailes.

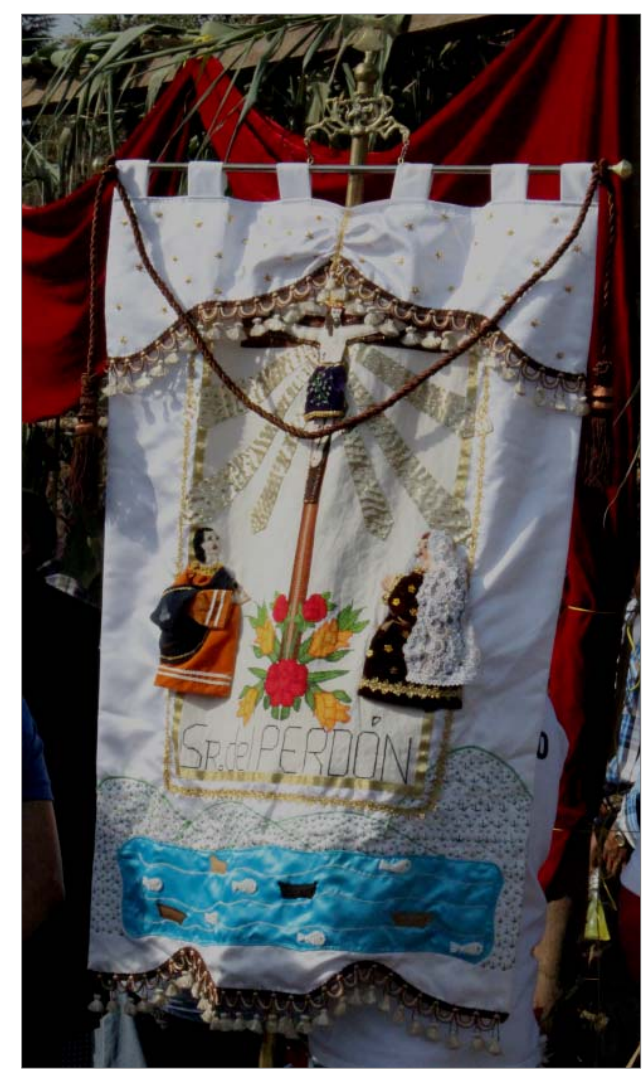

Fig. 3 Uno de los pendones que se utilizan en la procesión del señor del perdón. Nótese la iconografía del lago (Granados, mayo de 2014).

La fiesta del Corpus Christi está dedicada al Santísimo Sacramento. Esta celebración católica se lleva a cabo el jueves que sigue al noveno domingo después de la primera luna llena de primavera del hemisferio norte. Regularmente coincide con el fin de la temporada de secas, a fines de mayo o principios de junio. En Zirahuén, el festejo, al igual que en la fiesta del santo patrono, implica dos momentos claramente diferenciados: uno de interior y en el atrio de la iglesia y otro en la plazoleta externa al atrio. La estructura del Corpus es típicamente occidental, pues como sucede en algunos lugares de Europa, la fiesta está organizada por oficios. Después de la eucaristía, el día de la fiesta, el santísimo es expuesto y sale en una breve procesión al atrio, donde visitará los distintos altares montados por cada gremio: pescadores, agricultores, carniceros, albañiles, comerciantes, artesanos, restauranteros. Cada grupo gremial contrata a una banda de músicos, que toca una pieza cuando llega el santísimo frente al altar respectivo y cuando se va. Una vez terminada esta procesión, el santísimo es regresado a su sitio por el cura. 
Entonces comienza el segundo momento: en el atrio los grupos gremiales avanzan en una larga fila hacia la plazoleta. Cada grupo, acompañado por su banda musical, baila al compás de distintas melodías con sus productos característicos en la mano. Ya en la plazoleta, caminan en forma de una espiral levógira, mientras se lanzan los productos unos a otros y a los observadores, gente del pueblo. Al final de los gremios se encuentra el de los pescadores. Unos cargan a los pescados que serán arrojados, otros llevan una red con la que bailan imitando su actividad pesquera y un pescador más porta un enorme pez plateado hecho con palos de madera y cartón; este danza al ritmo de la música tratando de huir de la red de sus compañeros. Finalmente cuando el grupo de pescadores llega al centro, los que portan la red simulan atrapar al pez y ahí terminan las danzas de todos los gremios. Después todo el pueblo regresa al centro del atrio donde regalan comida y bebida. La fiesta se acompaña por un baile en el que toca una banda de música comercial.

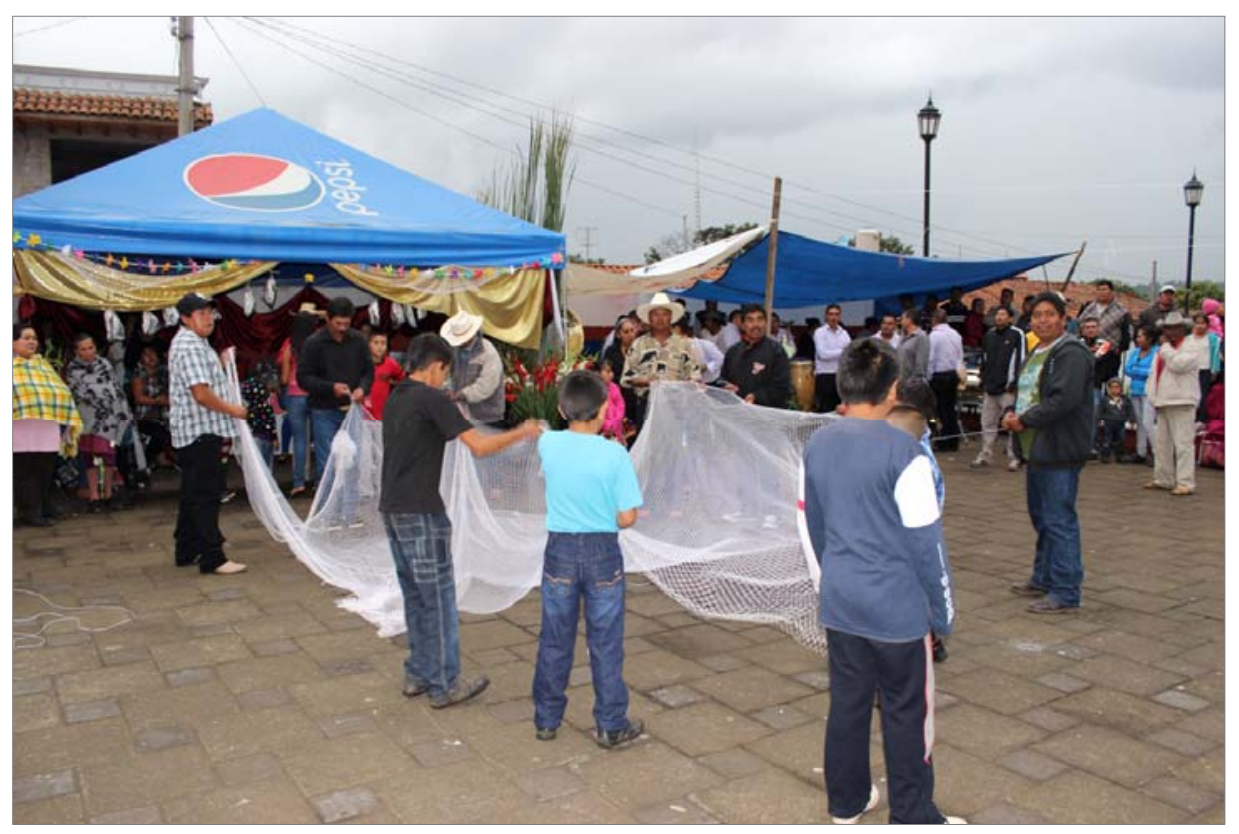

Fig. 4. Los pescadores de Zirahuén preparando la red para la danza, frente a la capilla del Corpus Christi (Granados, junio de 2014).

Ambas celebraciones tienen lugar en el umbral de la temporada de lluvias, aún en la de secas, y poseen, además del sentido católico, una función simbólica petitoria: la llegada de las lluvias y la de las buenas cosechas, por ejemplo, en el Corpus Christi el lanzamiento de productos parece un acto de magia simpatética para atraer la abundancia con abundancia ${ }^{10}$.

10 "La representación del comienzo del ciclo agrícola que subsiste en ciertos pueblos de Michoacán data de la época prehispánica, misma que estaba en consonancia con los ritos y fiestas 
No es casualidad que la fiesta del santo patrono se realice precisamente en la fecha de la Santa Cruz, ni que los habitantes ribereños suban al cerro para colgar en la cruz los listones y ofrecer algunos presentes. De alguna manera el ritual en el cerro trasciende la fiesta católica del Señor del Perdón y activa un complejo cultural subyacente entre los zirahuenses.

En la cosmovisión mesoamericana precolombina el símbolo cruciforme refiere el espacio numinoso de la fertilidad agraria y de la transformación hombre-vegetal; así lo sugieren los datos correspondientes a México central y a la región maya. En los cultos que se realizan en la actualidad en torno a la Santa Cruz, estos rasgos son manifiestos, si bien empalmados con el simbolismo católico. La presencia múltiple de tales ceremonias y la semejanza de sus prácticas, no parece ser resultado exclusivo del proceso de catequesis (Báez-Jorge, 2000: 337).

Los cerros se consideran lugares sagrados, grandes almacenes, que proyectan sus riquezas hacia el exterior. En las fuentes coloniales del Altiplano central, el cerro y el lago forman parte del mismo sistema acuático, conectado en el inframundo, el Tlalocan: ${ }^{11}$

La gente de aquí de Nueva España, los ancianos decían: "Estos [ríos] viene de allá, de allá parten hacia acá, de Tlalocan, porque son propiedad, porque salen de ella, de la diosa llamada Chalchiuhtli Icue”.

Y decían que los cerros tienen naturaleza oculta; solo por encima son de tierra, son de piedra; pero son como ollas, como cajas están llenos de agua, que allá está. Si en algún se quisiera romper la pared del cerro, se cubriría el mundo de agua. Y por esta causa se daba el nombre de altépetl a los asentamientos humanos, se decía: "Este altépetl, este río, de allá mana, del interior del cerro, de allá surge. Chalchíhutil Icue lo suelta de sus manos" (Códice Florentino apud López Austin, 2009: 54)

Más aún, en la zona lacustre los habitantes ribereños e isleños de Pátzcuaro y también los de Zirahuén consideran que ambos lagos se comunican mediante veneros, y que incluso puede observarse cuando el agua azul del lago de Zirahuén irrumpe en las aguas oscuras del lago de Pátzcuaro

que los michoaque realizaban orientadas a halagar a sus dioses para que enviaran buenas lluvias y por consiguiente buenas cosechas de maíz" (Cortés Máximo 2010: 181).

11 "Los informantes indígenas de Sahagún hablan de la bodega subterránea del Tlalocan como fuente de los manantiales que forman los ríos. No solo esto, sino que la personalidad divina del Monte era femenina: era la diosa de la falda de piedra verde preciosa, patrona de las aguas terrestres" (López Austin 2009: 53). 
(Comunicación personal del señor Marcos Salvador Diego Flores, pescador purépecha de 86 años que vive en Yunuén, una de las islas del lago de Pátzcuaro). Así también lo narró en 1679 fray Isidro Félix de Espinosa: “A la parte septentrional se forma la laguna de Sirahuén, que no consiente navegarse por un remolino que hace en el medio, capaz de sorberse un navío de alto bordo, y es tradición que por ocultos veneros se comunica con la laguna de Pátzcuaro" (Espinosa 1945: 24).

Por otra parte, el Corpus Christi evidencia la importancia del oficio de la pesca, que destaca no solo por la magnificencia de su altar, sino porque los pescadores marcan el final de la danza apoteósica. Quizás podría decirse que, por medio de esta procesión dancística espiral o en forma de "remolino" en la que el pueblo entero participa, la plazoleta se transforma simbólicamente en el lago, situación que se reafirma al final cuando el pez es atrapado. De esta manera estaríamos en ambas celebraciones ante dos escenarios que de por sí son claramente diferenciados: el mundo católico de la iglesia y su atrio, y el mundo acuático de reminiscencias prehispánicas representado por el cerro y el lago-plazoleta.

Tanto la fiesta del señor del Perdón como la del Corpus Christi tienen una función ritual asociada a la abundancia de lluvias y a las buenas cosechas, más aún, se desarrollan en espacios rituales que podrían estar vinculados con el agua. Los habitantes ribereños del lago conservan una memoria colectiva en la que sus antepasados participaban de celebraciones en espacios situados dentro de la paisajística ritual de Zirahuén, pero el destinatario de aquellas ceremonias ha cambiado.

En la Relación de Michoacán no encontramos una clara referencia a las costumbres rituales específicas del espacio que nos ocupa, pero sí encontramos en la primera parte del documento (que llegó incompleto a nuestras manos), la mención de una de las fiestas dedicadas a la diosa Cueravaperi, la de Sicuíndiro, celebrada en Zinapécuaro. Se presentaban los sacerdotes de los pueblos vecinos con sus dioses. El día de la fiesta, dos de sus principales se disfrazaban para representar a las nubes blanca y amarilla, colorada y negra. Sacrificaban esclavos y echaban sus corazones en las fuentes de Araro:

Y aquellas fuentes echan vaho de sí, y decían que de allí salían las nubes para llover y que las tenía en cargo esta dicha diosa Cueráuaperi y que ella las enviaba de oriente, donde estaba. Y por este respeto echaban aquella sangre en las dichas fuentes.

Era tenida en mucho en toda esta Provincia y nombrada en todas sus fábulas y oraciones y decían que era madre de todos los dioses de la tierra y que ella 
los envió a morar a las tierras, dándoles mieses y semillas que trujesen, como se ha contado en sus fábulas. Tenía sus cúes en el pueblo de Araro y otros pueblos, y su ídolo principal en un cu que está en el pueblo de Çinápequaro, encima de un cerro donde parece hoy en día derribado, y decía la gente que esta diosa enviaba las hambres a la tierra (Alcalá 2000: 331-332).

En este pasaje están presentes los dos espacios rituales a los que nos referimos: un cuerpo de agua y un cerro. Al parecer la fiesta celebrada en honor de esta diosa perseguía también un fin similar al de las fiestas que nos ocupan: la diosa era dueña de las mieses y semillas, ella enviaba las hambres a la tierra.

Actualmente, en algunas regiones del antiguo territorio mesoamericano se considera que en los cerros, barrancos, cuevas y cuerpos de agua (ríos, lagos, lagunas cenotes, ojos de agua, etc.) habitan seres de características frías:

En un cerro de la región de Chilapa mora una serpiente tan grande que ocupa todo el interior del cerro y no puede moverse, solo hace caminitos de saliva para atraer sus presas hasta su boca. Es peligroso aventurarse cerca de esos lugares así como por las grutas donde pueden vivir esos animales. La Lucerna, cerro me'phaa, es habitada por una ballena o una sirena (Neff Nuixa 2008: 326).

Estos seres son los encargados de enviar las lluvias. Así lo documentó Frederick Starr desde 1908 en Atla, localidad de Puebla y así lo verificó Israel Lazcarro muy recientemente (2009: 5), en la misma región:

We asked Don Pablo about the lake, concerning which we had heard. He says it is not as much visited as formerly. While used by Otomis, and others of this district, it is most favored by the Huaxtecs, parties of whom go there from long distances. They visit it when there is drought, for fear that the siren, who lives in it, is annoyed at their neglecting to make gifts; when there is too copious rain, they visit it to beg her to desist from sending more, and, when crops have been destroyed, to placate her anger. Sometimes two or three hundred Indians are in these companies. They bring muñecos of wood, cloth, clay, or even metal; such are shod, clad and hatted. They leave these upon the shore. They also bring seeds and strew them in the water, and some throw money in. They also make offerings of turkeys and hens. Sometimes these bands spend several days on the shore, dancing and eating (Starr 1908). 


\section{EL LAGO Y SUS ENCANTOS: NARRATIVA TRADICIONAL}

En Zirahuén existe un circuito narrativo de tradición oral sobre el lago: historias cotidianas de pesca, anécdotas en las que suceden fenómenos climáticos que ponen en riesgo la vida de los pescadores, consejos sobre cuándo, dónde y cómo pescar, así como una serie de narraciones recurrentes sobre una mujer muy hermosa con cola de pez que seduce a los hombres y los ahoga, y sobre una jícara bien adornada que engatusa a quien la mira. También se dice que el lago es mujer, que controla la pesca y que permite que las personas naden hacia su centro pero impide que salgan. Aunque no existe una ritualidad explícita en torno a la figura del lago, la abundancia de relatos sobre el mismo nos revela su importancia simbólica: todos conocen el misterio de Zirahuén, su encanto, y andan por el lago con cautela. Así ha sido siempre.

La primera vez que se llega al pueblo, sobre todo si se arriba por la parte noroeste (lugar de hoteles y cabañas construidos por y para gente externa a la comunidad), se tiene la impresión de que la sirena forma parte de la parafernalia turística: en el muelle particular donde se encuentra la propiedad de la familia Arreola, los niños cuentan a cambio de unos pesos una leyenda de corte romántico que les enseñan en las escuelas. Algunos de ellos incluso la escriben para memorizarla, como Salud Melchor de 12 años:

Cuenta la leyenda que Zirahuén... que la princesa Eréndira y Tanganzuán eran novios. Él era campesino y ella era una princesa. Y él un día fue a pedir su mano de la princesa. En el tiempo una guerra mandó para acá, y para que se pudiera casar con la princesa, su papá de la princesa lo mandó, al muchacho lo mandó a que fuera hiciera otra guerra. Y entonces aquí, la princesa andaba en un cerro con más de su reino. Y entonces, ahí el capitán la vio y se enamoró. Y allí, un día ella no tenía miedo de nada, y entons allí llegó el capitán y se la llevó. Y ahí, este, en el Rincón de Agua Verde, ahí se puso a llorar a cantarazos y allí, se fue creciendo el lago.

Este relato es una construcción narrativa inspirada en la versión del historiador y abogado Eduardo Ruiz; forma parte del segundo volumen de su libro Michoacán: paisajes, tradiciones y leyendas. Este texto retoma al personaje literario Eréndira, y al personaje histórico del siglo XVI, cuyas peripecias figuran en la Relación de Michoacán, Tanganxoan II (cf. Ruiz 1900).

Si en Zirahuén se pregunta sobre el origen del lago, las personas relatarán esta versión "oficial”. Sin embargo, si a un adulto se le pregunta si sus abuelos le contaban este relato con los mismos motivos y personajes, contestará que no. El lago entonces se construye de forma distinta: como un ente animado 
con voluntad propia. Se dice - como pudimos observar en el relato de Gabino Calvillo que aparece en la introducción de este texto- que es mujer y su distribución corporal concuerda con el paisaje: la cabeza se localiza al sureste en el Rincón de Agua Verde, los pies al noroeste hacia el pueblo de Zirahuén, mientras que las manos dan, una al este y otra al oeste, en forma de cruz.

En la narrativa tradicional el paraje de Agua Verde es un lugar destacado. Se encuentra al suroeste. Según Salud Padilla, es uno de los ojos de agua que alimentan al lago: "El agua es nacida de aquí, nacida porque hay ojos de aguas, hay veneros donde está naciendo el agua. Está naciendo el agua y está entrando al agua a la laguna”. Eliodoro Sanabria insiste en que Zirahuén se originó en este espacio, su padre se lo contó y lo verificó en "un libro muy antiguo que tiene un señor de Copándaro”. Durante mis estancias de campo no pude indagar más sobre la existencia y el paradero del libro.

El lago fue una traición, simplemente, de una muchacha. Esa era de, era de Agua Verde esa muchacha, y venía al lago. Ya era una joven, porque ella ya podía con el cántaro del agua. Y que tenían una cubetita amarrada para sacar la agua y llenaba su cántaro. Y ya cuando se iba luego luego agrandando el pozo del agua, porque más y más se iba saliendo, ya ella ya llegaba y le hacía al cántaro al hombro y ya. Hasta que un día se la llevó el cántaro a la muchacha: lo jaló, lo jaló y no estaba bien parada, yo creo, y se fue, y allí se quedó el encanto de ella, porque fue pa arriba y pa arriba y pa arriba y pa arriba, hasta que se formó el charco siempre grande. Y luego de ahí fue y ahí fue y ahí fue, y áhi está el lago.

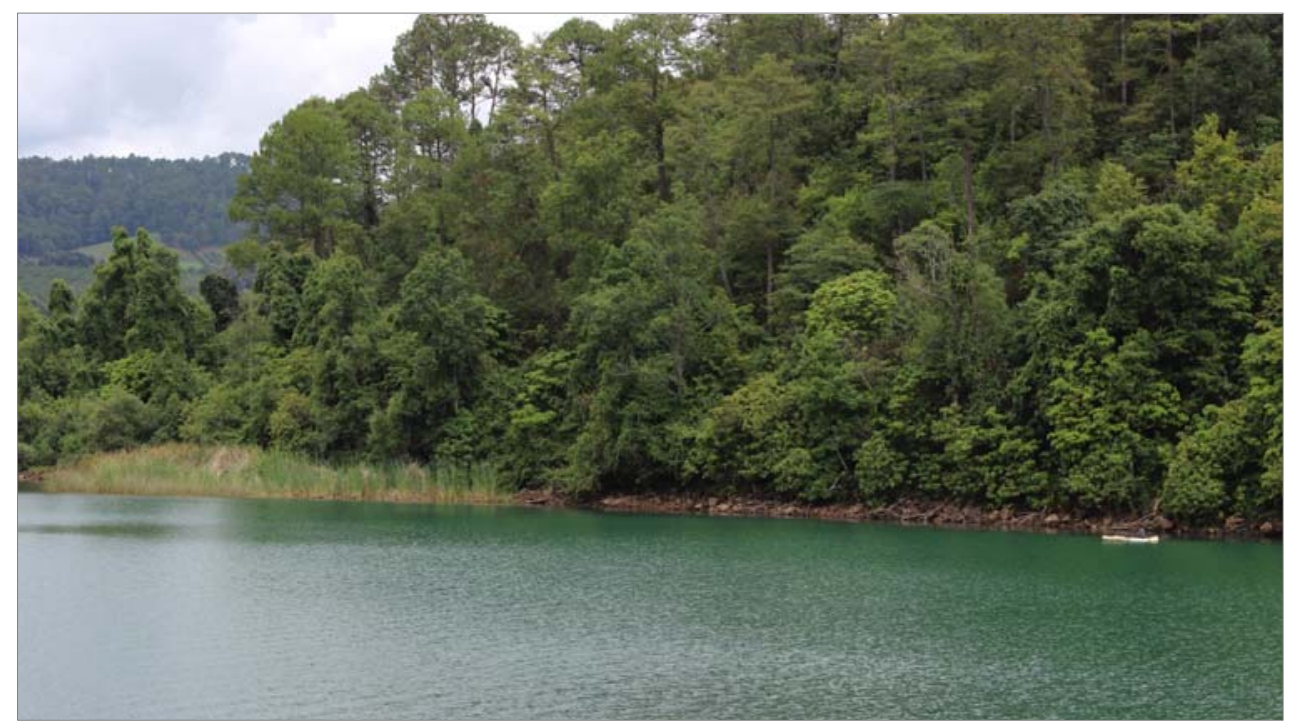

Fig. 5. El paraje de Agua Verde se encuentra al Suroeste del lago. Este es el lugar en el que, según la narrativa de tradición oral, se origina el lago (Granados, enero de 2013). 
La calidad del agua es especial, tiene una serie de tonos azules y verdes que cambian con la temporada del año y la luz del día. Se dice que son aguas difíciles de nadar: uno puede adentrarse rápidamente en el lago, que te jala hacia adentro, pero se deberá invertir el doble de esfuerzo para salir, pues el agua se vuelve fría y pesada, cuesta trabajo librarse de ella; muchos terminan ahogados, como relata Gabino Calvillo:

\begin{abstract}
Ahora, mire, cuando nos íbamos a bañar, teníamos bien calado eso de... pus yo sí calé, porque mire, eso de, mire, pa entrar pa bañarnos esta agua tiene, este lago tiene un misterio, porque nosotros mismos lo notamos el misterio que tiene la laguna. Mire, para entrar de aquí para allá, va uno nadando luego bocarriba, como uno puede nadar. Entra en dos manotadas, ya va por allá en la ribera del lago pa dentro; y pa salir, por eso muchos se ahogan aquí, harta gente se ha ahogado, porque le dan pa dentro, por eso se fueron lejos, y pa salir no aguantan. Muchos se han ahogado, no alcanzan a salir. Porque pa salir, mire, se atarca, sientes el agua fría, y luego, este, ves la orilla, y duro y duro y duro y la orilla se ve relejos. Sí sale uno porque ya sabe, por eso los que visitan aquí necesitan, pues, tantearle. No meterse hondo, porque simplemente no salen. Se atarcan y se ahogan, pues. No van a salir, pus se ve la orilla lejos. Ese misterio tiene el lago, porque nosotros lo hemos calado. Y se ha ahogado mucha gente de fuera y de aquí también.
\end{abstract}

El lago, se dice, necesita ahogados; la gente de la ribera sabe que exige una cuota anual. Su reclamo se hace notorio cuando sus aguas se embravecen y adquieren un tono más intenso. En las orillas se forman grandes olas y el viento sopla todo el tiempo. Los lugareños toman sus precauciones, los foráneos no se dan cuenta. Algunos, como Fernando Calvillo, afirman que se lleva siempre a cuatro personas:

Aquí el lago, alguna gente lo conoce porque cuando el lago hace ruido, o sea, orita está haciendo ruido por el aire, o sea, el aire normal que hace, pero hay veces que el aire hace muy fuerte, hace muy fuerte $y$, este, y se oye que hace mucho ruido. Dicen que está enojado, es cuando se ahoga la gente. Este, antes de que se ahogaran los que se ahogaron, se ahogaron tres, cuatro, así estaba un día antes el lago haciendo ese movimiento, pues. Y sí, al siguiente día se ahogaron tres. Después todavía duró como ocho días y se volvió a ahogar el que quedó allí, porque decían que el lago todavía estaba enojado, pues, que, que pedía más ahogados. Y que siempre, cada vez que pide, son cuatro. Se ahogaron cuatro personas ahora que pasó esto, ¿̇eh? Pero eso son historias que cuentan, uno no las conoce, pues. Nada más a la gente que es de más antes que dice que eso es lo que sucede y sí. 
Pero el lago no se conforma con los escasos nadadores de fuera; para obtener más víctimas se presenta como una mujer hermosa con largos cabellos rizados, que aparece bañándose en parajes solitarios, ya sea de noche o de día: es la sirena que, a diferencia de otras entidades femeninas, se deja ver en los pueblos ribereños por hombres y por mujeres. La sirena tiene apetito sexual a juzgar por dos características: todos los ahogados son hombres y todos son jóvenes. Según Salud Padilla: "Yo creo que sí escoge, porque no es tan verenga, no se lleva puros viejitos, sino se lleva nuevos; puros nuevos, se lleva hasta la edad de quince años pa arriba. Porque hasta niños de quince años se ha llevado". Hipnotiza a sus víctimas, les despierta un deseo obsesivo que los conduce a la sepultura: ella los llama, como le sucedió al primo de Guillermina Patricio:

Se llamaba mi tío Gonzalo. Y tenía un hijo que se llamaba Gonzalo también. Y ese, él todas las tardes, pues, se iba. Haga de cuenta que ya llegaba la tardecita, cuando estaba el sol y se iba y se estaba, pues, decía mi tío que se estaba allá sentado y allá sentado. Y que ya un día sí les platicó, pues, que les dijo:

-No dice, es que mira, una muchacha bien bonita me llama y me llama dice-. Y me llama y me llama esa muchacha.

Y que le decían:

-iAh, te creemos qué!

Ya ve pues los amigos. Y que no, que no le creían.

-Van a ver que sí, dice. Sí me llama, pues, dice.

Y un día antes les dijo, o salió la sirena, pues, pues qué más.

-Salió la muchacha, pero bien chula muchacha, dice. Y me vuelve a llamar y me vuelve a llamar, pero... ora sí voy a ver qué quiere, pues, al fin que sé nadar bien.

Y al otro día se metió y se ahogó, ya lo sacaron ahogado. Por eso le digo él platicó antes que sí, pues, sí existe la sirena, porque a él lo llamaba, pues. Y que lo llamaba y lo llamaba. Y a ver, sí se ahogó también. Por eso sí, de que existe, pero no toda la gente tiene, pues el don de verla. Porque pus no, no, pues, la ven. Mucha gente pus dicen que sí y que sí.

Congruente con su apetito, la gente dice que la sirena mantiene a los ahogados en su palacio. Aquí el relato de Juan Melchor:

Se hace muy extraño que la persona que se ahoga, aunque lo vea uno que está aquí en la orilla, pero es muy, aquí se juntan todos los compañeros pa sacar el cuerpo de la persona, pues que se queda porque se ahoga mucha gente de fuera, de Uruapan, Morelia, este, aquí a los alrededores Santa Clara del Cobre, Opopeo, bastante turismo se ha ahogado, pues, aquí, por lo 
mismo que se meten a jugar, que dicen: "No, pus que yo no me hogo y quién sabe qué tanto".

Pus órale pues, se los lleva y no los vuelven a aparecer hasta los dos, tres días. Y aunque diga uno, pues, que esta aquí en el, en donde dice que ahí quedó, no se encuentra esa persona, ya hasta que los vuelven a regresar donde los vuelven a tomar el encanto que sería la sirena, pues. Y se los lleva a su palacio. Y ahora sí que es lo que uno pues...

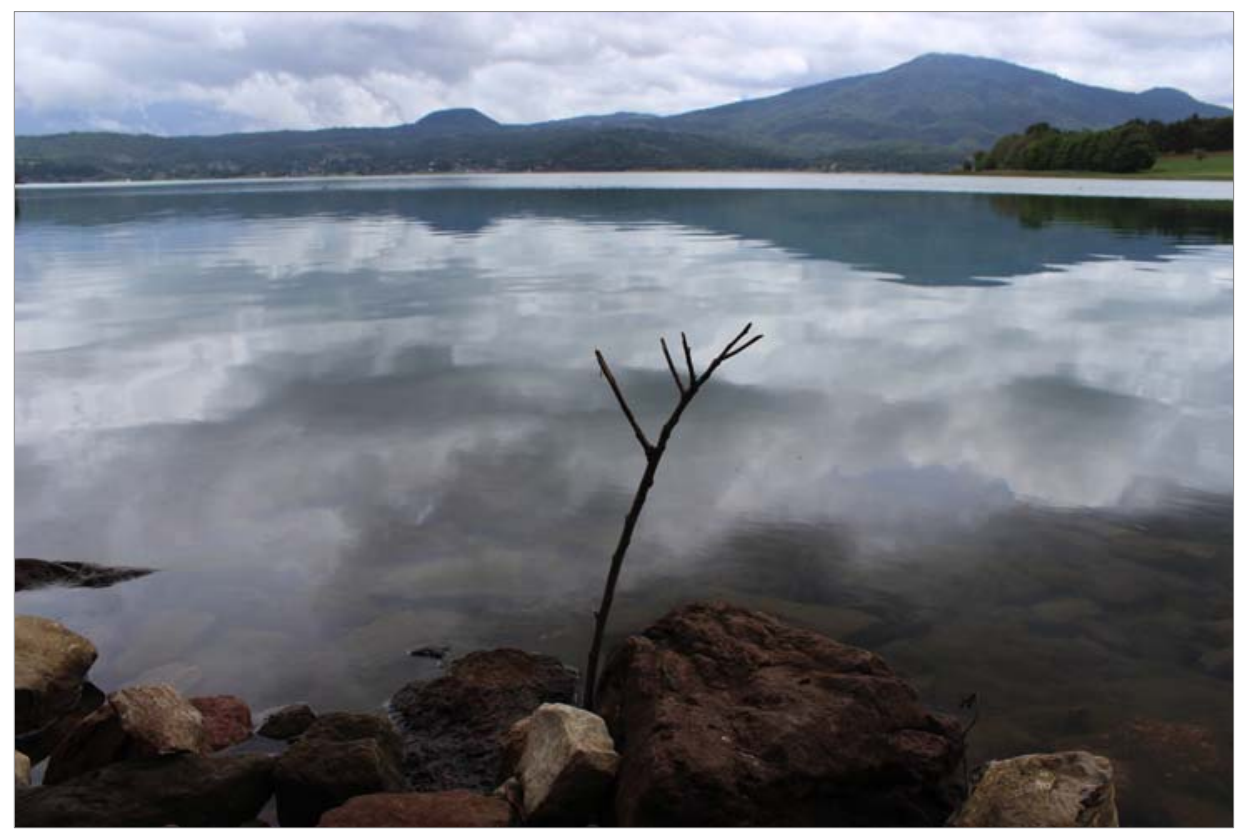

Fig. 6. Paraje al suroeste de Zirahuén, cerca del Rincón de Agua Verde (Granados, junio de 2013).

Algunas de estas descripciones afirman que los libera hasta que los hombres se vacían, como contó Salud Padilla: "los trae alrededor del agua, y cuando ya se vacían, y que ya están llenos de agua y todo, o será que ya que se, que ya no están, pues, que ya no tengan agua, ya los avienta pa arriba, pa arriba”.

El lago, se dice, tiene otra manera de atrapar humanos: una jícara muy "adornadita" que aparece en la orilla. Una vez que la persona la mira, trata de tomarla, pero la jícara poco a poco se mete hacia el centro del cuerpo de agua, alejándose de su persecutor. Finalmente la persona va por ella con el fin de alcanzarla hasta que termina por ahogarse. Así lo narró María Teresa Melchor:

Esas jicaritas son de esas como las que venden en Pátzcuaro pintadas, sí las conoce, ¿no? Son unas batellitas. Esas sí yo no las he visto, pa qué le echo mentiras. Pero cuentan que si usted ve esa batellita que anda moviéndose ahí junto a la laguna, que esa batellita se va metiendo y metiendo que pa que la 
quieran agarrar, pues, y que ya se los lleva hasta donde ya... Pero yo de eso, pues, no les sabría decir; nomás que dicen que salía esa jicarita, pero quién sabe uno, pues, no la he visto también, pa qué digo ¿̇verdad?, lo que no.

La mujer-lago no solo se materializa en jícara y en sirena, sino que tiene incidencia sobre los peces. La pesca se sujeta a ciclos naturales; la Semana Santa es una época propicia para ello. Los pescadores salen por la tarde y regresan cuando ya está oscuro. En las noches de luna llena la pesca puede prolongarse hasta media noche, los pescadores hacen varios lances. Cada tipo de pez debe ser atrapado de forma distinta: para el blanco o cuerepo las redes se tienden toda la noche, para el charal es por las mañanas cuando apenas está amaneciendo. Se cree que la sirena controla la producción de peces, es donadora, aunque debido a su carácter voluntarioso a veces no los suelta. En ocasiones lleva su encanto a un sitio determinado y tienta a los pescadores para conseguir ahogados. El pescador avezado sabe cuándo retirarse para evitar su muerte. Los hermanos del suegro de Salud Padilla no supieron hacerlo a tiempo:

Porque dice que habían ido a pescar, ellos eran tres hermanos, y iban cuatro, buscaban un peón. Y los tres eran hermanos. Y que ya se entraron y que anduvieron todo el día, todo el día pescando y que no encontraban nada. Y que dicen, y que dicen:

-Ya vamos a echar el último, a ver quién quita y en este sí agarráramos algo.

Pues sí, dice que áhi namás, habrá sido el encanto de la Sirena, que áhi namás que sale un, una, este, una garza blanca, grandota -les decían yorchas-, $y$ ya pues uno dice:

-Que sale, dice, la esa yorcha blanca, con un pescado así en el hocico. Dice que les dijo:

-Ahora sí vamos a sacar pescados, ahora sí vamos a sacar pescados.

Dice que sí:

- Vamos a echarlo áhi on tá. Ahí va a haber.

Pues que sí, que tendieron la red pa pescar y que van sintiendo la bolsa de la red pesada.

-Mmm, ya traemos rehartos pescados.

Pus era la sirena, el encanto que los llamó, y que allí había pescados pa echárselos. Dice que ya que luego cuando vaciaron la bolsa sacaron pero puro pescado de lo mejor, porque más antes había pescado blanco y pesaban hasta medio kilo o kilo, grandotote el pescado, entons había esos pescados grandototes, y que puro pescado escogido. Puro chulo pescado grande. Y se vende por kilo, los kilos lo dan a 350 un kilo, 400, 350 el kilo, era del más caro. Y puro pescado de ese, pues era el encanto. Dice que ya cuando ellos vieron lo que vaciaron, no alcanzaron a vaciar cuando se voltió pa bajo el 
barco. Y que ya se voltió el barco, y nada más se alcanzaban a ver el puro alumbre del pescado, y no se alcanzaron a salvar dos y uno se quedó.

Hasta aquí las descripciones narrativas sobre el lago, su comportamiento, sus necesidades y los actos de los ribereños en torno a ello. El lago-mujer Zirahuén, como podemos observar en los relatos, se desdobla en dos entidades que tienen las mismas características del lago y se comportan como él: una hermosa muchacha con cola de pez y una jícara bien adornada. Ambas tienen la misma función simbólica: en un acto de inversión, pescan a los hombres.

\section{EL LAGO-MUJER EN LAS FUENTES PREHISPÁNICAS Y COLONIALES}

Resulta necesario, antes de proseguir con el análisis de los materiales, aclarar que como base de este estudio tomaré uno de los axiomas fundamentales de la cosmovisión mesoamericana: la taxonomía bipartita del cosmos. Para los pueblos mesoamericanos (y actualmente para distintos grupos étnicos) el universo se regía por dos principios básicos: lo femenino y lo masculino, conviviendo de forma permanente y creando un flujo de fuerzas que permitía la continuidad vida-muerte. Cada uno de ellos estaba asociado a campos semánticos bien definidos. Lo masculino estaba conformado por el universo de arriba: el supramundo, el sol, lo seco, lo caliente, lo estéril, el presente, el orden, lo ligero, los instrumentos de aliento, el maíz, el color amarillo, la guacamaya, el quetzal, la vida. Lo femenino, en cambio, implicaba al universo de abajo: al inframundo, la luna, la oscuridad, lo húmedo, lo frío, la fertilidad, el pasado y el futuro, el caos, lo pesado, los instrumentos de percusión, el cacao, el color verde/azul, los animales nocturnos o acuáticos, la serpiente, el jaguar, la iguana, la lagartija, la muerte. El misionero fray Juan de Torquemada describe este concepto en su Monarquía indiana:

Entre los dioses que estos ciegos mexicanos fingieron tener y ser mayores que otros, fueron dos; uno llamado Ometecuhtli, que quiere decir dos hidalgos o caballeros; y el otro llamado Omecihuatl, que quiere decir dos mujeres. De manera que, según lo dicho, está muy claro de entender que tenían opinión, que los que regían y gobernaban el mundo, eran dos (conviene a saber), un dios y una diosa, de los cuales el uno, que era el dios hombre, obraba en todo el género de los varones; y el otro, que era la diosa, criaba y obraba en todo el género de las mujeres (1975: 67). 
La sirena forma parte del repertorio europeo de seres fantásticos que tuvo una acogida singular entre los pueblos mesoamericanos. Sin embargo, la figura femenina con características acuáticas ya existía en el área cultural desde tiempos remotos. No se trata de una sirena propiamente dicha, sino de distintas deidades femeninas que presentan rasgos serpentinos. Recordemos que en el mundo simbólico existe una fuerte identificación entre el agua y la serpiente; en muchas culturas la representación iconográfica del líquido vital es una línea ondulada semejante a una serpiente en movimiento. Entre los nahuas del Altiplano central aparece en las fuentes y en la iconografía de origen prehispánico el batraceo, pez o generalmente lagarto primigenio que da origen a la vida terrestre: Cipactli. En el documento del siglo XVI, Historia de los mexicanos por sus pinturas, se dice: "Y luego crearon los cielos allende del treceno; e hicieron el agua, y en ella crearon a un pez grande que se dice Cipactli, que es como caimán, y de este pez hicieron la tierra" (Tena 2011: 29). $\mathrm{Su}$ figura también preside a la primera trecena en el ciclo calendárico de 260 días (tonalámatl) y en el calendario venusino ${ }^{12}$. Entre los mayas esta figura recibía el nombre de Itzam Cab Ain ${ }^{13}$.

Los dioses mesoamericanos presentan una cualidad que los hace adaptables: se fusionan y se fisionan ${ }^{14}$. Así, de la diosa madre lagarto derivan una serie de representaciones que aluden a aspectos específicos: Chalchiuhtlicue es la diosa del agua terrestre ${ }^{15}$; Tlaltecuhtli es la deidad de la

12 "Entre los habitantes del México Central del período postclásico, el caimán era un símbolo o metáfora muy común de alusión a la tierra (Seler 1902-1923, 4: 646-653). En el grupo Borgia de códices, el lomo áspero y escamoso del caimán se utiliza con frecuencia para aludir a la superficie de la tierra (por ejemplo, Borgia 7, 27, 39-40, 42 y 53; Vaticanus B 69; Fejervary-Mayer 28) (Taube 2009: 1).

13 A la luz de la pintura de Cobá y de otras escenas mayas, resulta claro que los mayas yucatecos del período postclásico tenían una concepción muy parecida del caimán terrestre a la de los habitantes del altiplano mexicano. En ambas regiones, al caimán se le identificaba estrechamente con una deidad anciana, asociada a su vez con la creación y el sustento. Si bien no se conocen ejemplos de la metáfora del caimán-tierra anteriores al período postclásico en el centro de México, hay fuertes indicaciones de que se hallaba presente entre los mayas del período clásico. No obstante, la identificación de Itzamná con el caimán en forma de Itzam Cab Ain es característica sobre todo del período postclásico entre los mayas. Muy probablemente, el uso yucateco del vocablo itzam para designar una ballena o caimán se derive de la tardía identificación de Itzamná con el caimán cosmológico (Taube 2009: 9).

14 Véase López Austin (1983: 75-87).

15 "La cuarta diosa, era del agua, llamada Chalchiuhtlicue. A ésta atribuían todos los peligros del agua y del mar, como autora de ellos, y por esto temían y reverenciaban y le hacían sacrificios y ofrendas, en su fiesta; decían que era hermana de los dioses Tlaloques” (Sahagún 2006: 61). 
tierra ${ }^{16}$; Coatlicue, "la de la falda de serpientes" y madre de Huitzilopochtli, es también una deidad de la tierra ataviada como guerrera; Cihuacóatl es la mujer serpiente, una diosa de la fertilidad invocada por las parteras en casos difíciles, que "también tenía aspectos negativos, pues se cuenta que esta diosa mandaba adversidades como pobreza, abatimiento, trabajos" (López Hernández 2012: 78). Así, las deidades femeninas remitían a un mismo ámbito simbólico: eran diosas terrestres de calidad acuática vinculadas con ciclos agrícolas, fertilidad y muerte.

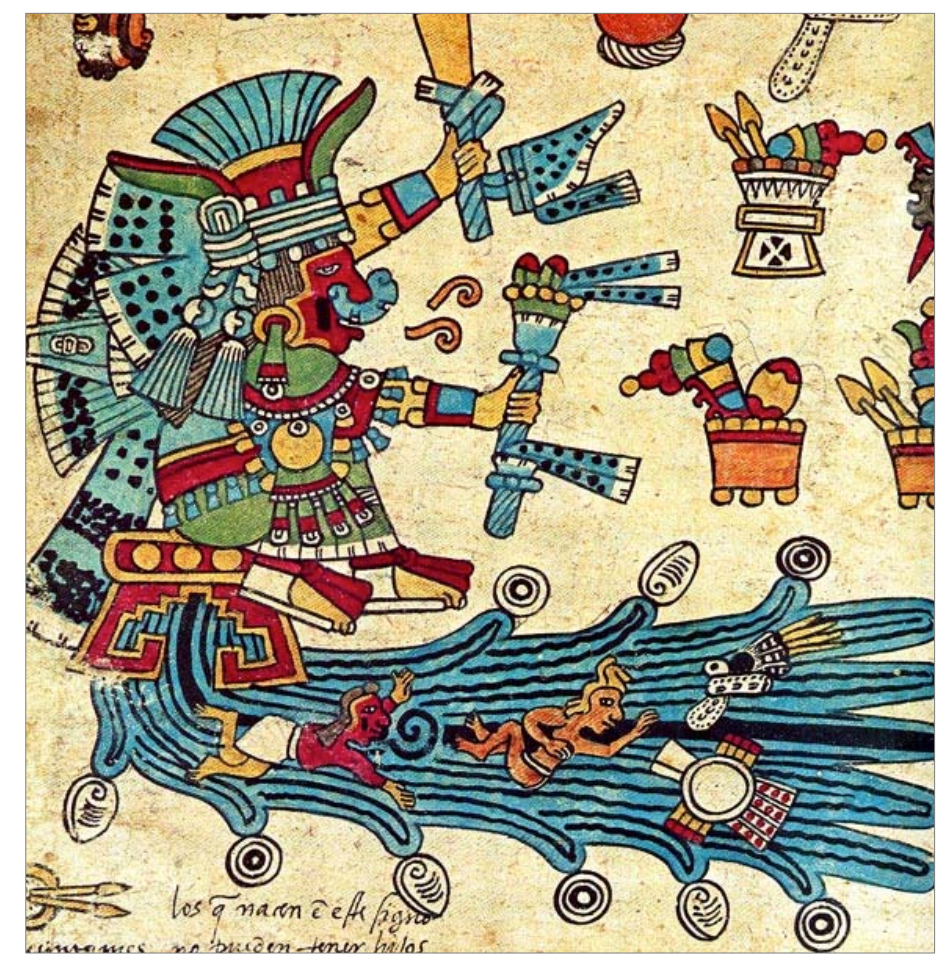

Fig. 7. Chalchiuhtlicue en el Codex Borbonicus.

Vale la pena mencionar la deidad patrona de los otomíes del lago de Xaltocan, una entidad que habitaba en el cuerpo de agua, propiciaba la fertilidad y proveía de peces: "en cuanto había guerra, humanamente les hablaba a menudo su dios, que salía del agua y se les aparecía, se llamaba Acpaxapo; es una gran culebra; su rostro, de mujer; su cabello enteramente igual al de las mujeres, así como el suave olor" (Velázquez 1992: 25). La caracterización de esta diosa se asemeja mucho más a la de la sirena como la conocemos hoy en día.

16 "Después, estando todos cuatro dioses juntos, hicieron del peje Cipactli la tierra, a la cual dijeron Tlaltecuhtli, y pintalo como dios de la tierra, tendido sobre un pescado, por haberse hecho de él" (Tena 2011: 31). 
En las fuentes coloniales sobre el occidente de México encontramos descritas a dos deidades con características similares a las de la diosa madre de los nahuas: Cueravaperi y Xaratanga. En la Relación sobre la residencia de Michoacán, escrita en 1585 por el jesuita Francisco Ramírez, Cueravaperi - deidad aludida líneas arriba - era considerada la madre tierra:

Lo qual todo, decían, salía de las espaldas de una diosa que los dioses pusieron en la tierra, que tenía la cabeza hacia poniente, y los pies hacia oriente, y un brazo a septentrión, y otro a meridión; y el dios del mar la tenía de la cabeza; y la madre de los dioses de los pies; y otras dos diosas, una de un brazo y otra de otro, porque no se cayese (Ramírez 1959: 493-494).

De acuerdo a estas fuentes, el cuerpo de Cueravaperi estaba en posición de cruz. Resulta curioso que la descripción del lago-mujer de Gabino Calvillo que leímos líneas arriba, sea tan parecida. Cada parte del cuerpo corresponde a uno de los rumbos del universo: norte, sur, este y oeste. En las cosmogonías mesoamericanas el universo tenía una composición cruciforme, cada rumbo estaba asociado con deidades, números y colores, que formaban parte del código que rige la vida del hombre: el espacio y el tiempo. Desde etapas muy tempranas aparece el símbolo de la cruz para representar esta distribución cuatripartita del universo:

La cruz de Quetzalcóatl, la cruz de Dainzú, Oaxaca, las cruces de Palenque y Xochicalco, son algunos ejemplos que expresan la importancia de este concepto. Los esquemas señalan con sus brazos un rumbo cardinal, un espacio que domina ciertos periodos y augurios (Morante López 2000: 35).

La construcción discursiva de la geografía ritual del lago-mujer en forma de cruz emana de un concepto de larga raigambre entre los pueblos mesoamericanos; Gabino Calvillo, el narrador de Zirahuén, duplica esa proyección de la diosa madre tierra en un espacio más localizado, y por ende, al otorgarle la misma distribución original, lo sacraliza. El historiador Alfredo López Austin explica el fenómeno:

La estructura se reproduce en sucesivas proyecciones que no solo trasladan el isomorfismo, sino la correspondiente isonomía. Así, por ejemplo, las características del eje cósmico se proyectan a los cuatro extremos de la superficie terrestre o a las grandes montañas; de éstas pasan propiedades, forma $\mathrm{y}$ función a accidentes topográficos menores o a los templos piramidales, y de los templos se diseminan en los altares familiares. El universo se convierte así en un enorme sistema que da coherencia a sus partes y norma las acciones tanto divinas como humanas (2013: 7-8). 
Por otro lado, la diosa Xaratanga cuyo nombre, según la lingüista Cristina Monzón, podría significar 'la que muestra algo', 'pare plantas' o 'la que hace que otro tenga placer, gusto, contento”' (cf. Monzón 2005: 152-154), era una deidad agrícola. En la Relación de Michoacán Xaratanga es descrita como una diosa de los tarascos establecida en Tzintzutzan; ella había traído a la tierra el "ají colorado y verde y amarillo [...], los frísoles colorados y negros, [...] el maíz colorado y lo pintado". Se la ataviaba con guirnaldas y sartales hechos con estos productos. Se la identifica con la esposa del dios del infierno, de la que fray Ramírez nos dice: "Y, para tornar a restaurar las demás cosas, mandaron al dios del infierno que diese orden en eso; y, concibiendo su muger, vino a parir todas las demás plantas y árboles, como están” (Ramírez 1959: 493-494).

Xaratanga transformó en culebras a sus sacerdotes y a las hermanas de ellos cuando, durante la fiesta de la diosa, estando borrachos se colocaron sus atavíos y después, para quitarse la embriaguez, enviaron a las mujeres por pescado para comer:

Y como no tuviesen red para pescar tomaron una cesta, y la una andaba con ella a la ribera, y la otra ojeaba el pescado y las pobres, ¿cómo habían de tomar pescado, que se lo habíen ya escondido Xarátanga, que era tan gran diosa? Y después de haber trabajado mucho en buscar pescado toparon con una culebra grande y alzáronla en la mano, en un lugar llamado Uncúçepu y lleváronla a su casa con mucho regocijo. Y los sacerdotes llamados Vatárecha, de Xarátanga, uno que se llamaba Quáhuen y su hermano menor llamado Camejan y sus hermanas llamadas Pazínvaue y Zucúraue las saludaron y dijeron: "Seáis bienvenidas, hermanas. ¿Traéis siquiera algunos pececillos?”. Respondieron ellas: "Señores, no habemos tomado nada, mas no sabemos qués esto que traemos aquí". Respondieron ellos: "También es pescado eso, y es de comer; chamuscalda en el fuego para quitar el pellejo y hacé unas poleadas, y este pescado cortaldo en pedazos y echaldo en la olla y ponelda al fuego para quitar la embriaguez". Y haciendo aquella comida a mediodía, asentáronse en su casa a comer aquella culebra cocida con maíz, y ya que era puesto el sol, empezáronse a rascar y arañar el cuerpo, que se querían tornar culebras. Y siendo ya hacia la media noche, tiniendo los pies junctos, que se les habían tornado cola de culebra, empenzaron a verter lágrimas y estando ya verdinegros de color de las culebras, estaban ansí dentro de su casa todas cuatro. Y saliendo de mañana entraron en la laguna, una tras otra, y iban derechas hacia Vayámeo, cabe Santa Fe, y iban echando espuma hacia arriba y haciendo olas hacia donde estaban los chichimecas llamados hiyocan y diéronles voces, y ellas dieron la vuelta, y volvieron hacia un monte de la cibdad llamado Taríacaherio, y entráronse allí en la tierra 
todas cuatro. Y donde entraron se llama Quáhuen yncházequaro, del nombre de aquellos que se tornaron culebras, y ansí desaparecieron (Alcalá 2000: 351).

En este pasaje observamos algunos de los atributos de la diosa: no solo tiene un carácter meramente agrícola, sino que como sucede con las diosas terrestres, también presenta características acuáticas. Ante la transgresión de las cuatro personas, la diosa (que controla la vida de las criaturas lacustres) decide esconder los peces y otorgarles a cambio una culebra - símbolo del mundo femenino- que tiene un efecto fatal: al ser ingerida por los transgresores los convierte en culebras. Llama la atención que la temporalidad en la que se verifica la transformación, es la noche, también de calidad femenina.

Los relatos sobre el lago-mujer replican este modelo. Como vimos, el encanto tiene control sobre los peces: a veces envía grandes cantidades para propiciar la muerte de los pescadores, otras los esconde. Como se cuenta en uno de los relatos, también toma a sus víctimas en tandas de cuatro. Una de las versiones sobre cómo surgió la sirena es semejante a este pasaje: una muchacha desobediente fue castigada por Dios porque se fue a nadar al lago un Jueves Santo. Así lo narró María Teresa Melchor:

Y que se metió a bañar. Y que, este, se volvió, pues, pescado. O sea, la cola nada más, los pies se unieron así como la cola, pues, y de aquí pa arriba ella es mujer. Es una mujer. Y entonces ella no creyó, y entonces eso le pasó por desobedecer. Y dicen que es la muchacha que anda, pues, en el agua, y sí, pues.

Otra característica de la diosa Xaratanga es su carácter sexual. En un pasaje del documento colonial citado se describen ciertas prácticas vinculadas con la diosa:

Zurunban, mi suegro, tiene la diosa Xarátanga en guarda y aquella su hija llamada Mahuina, es mala: que se iba al tiangues y hizo que le heciesen en el tiangues una tienda o pabellón llamado Xupáquatá y puniese, como ponían, a la diosa Xarátanga en aquel pabellón,hecha una cámara de mantas pintadas y asentábase encima de muchas mantas. $\mathrm{Y}$ estando en aquel pabellón decía que le llamasen los mancebos hermosos que pasaban por el mercado y todo el día se juntaba con ellos, dentro de aquel pabellón. Y decía que les dijesen: “Si yo fuera varón, ¿̇no me juntara con alguna mujer?”. Esto hacía aquella mujer (Alcalá 2000: 467). 
Al parecer, la imagen de la diosa Xaratanga estaba asociada al placer carnal. Entre los pueblos mesoamericanos las diosas agrícolas eran entidades con una fuerte carga simbólica sexual: "la unión sexual era la expresión suprema de la creatividad y de la fertilidad" (González Torres 2010: 72). Así, en la división bipartita del mundo mesoamericano, en lo femenino...

[...] recaía todo el peso de la vida sexual, particularmente el de la reproducción. La sexualidad, por tanto, se asociaba a las categorías clasificatorias de lo terrenal, lo frío, muerto, incluso de lo maloliente, podrido y oscuro del vientre preñado, donde el semen ya corrupto servía para crear una nueva vida (López Austin 2010: 32).

Las deidades femeninas agrícolas eran representadas con atributos que aludían a su sexualidad. Algunas aparecen en las fuentes como transgresoras: Tlazoltéotl, Xochiquétzal, Ixcuina, Itzpapálotl. Como hemos visto, el concepto de lo femenino en el lago no solo configura el paisaje ritual: el lago-mujer necesita alimentarse para aquietarse, para "silenciarse". Ahoga solo a hombres jóvenes y los mantiene en su palacio hasta que "los vacía". Aquí el verbo vaciar pareciera que tiene también una connotación sexual asociada a la eyaculación. En este sentido y sin dejar de lado el contexto mesoamericano, los testimonios sobre cómo aparecen los ahogados recuerdan algunos de los materiales que fray Bernadino de Sahagún consigna, como el relativo al consumo de la mazacóatl, una culebra con cuernos, para tener "acceso a cuatro o cinco mujeres, a cada una cuatro o cinco veces y los que esto hacen mueren porque se vacían de toda la substancia de su cuerpo y se secan, y se mueren desechos y chupados" (Sahagún 2006: 149-150).

\section{LA SIRENA Y LA JÍCARA EN LAS FUENTES ETNOGRÁFICAS}

La sirena con cola de pescado también aparece actualmente en otras literaturas orales de los pueblos de tradición mesoamericana. Entre los otomíes de la Huasteca, Xumfø Dehe es una entidad que cuida y provee el agua de los pozos, manantiales y estanques que utilizan en las comunidades, pero su morada es el mar:

Para los otomíes, se trata de una mujer extremadamente bella, aunque la mitad de su cuerpo parece la de un reptil (una víbora con frecuencia), o bien la de un pescado. No es extraño que aparezcan manantiales ahí donde se ven serpientes. De hecho, si se mata a las serpientes, se corre el riesgo de que los manantiales se sequen. En algunos casos es mitad mujer y mitad pájaro. En los ojos de agua cristalina, suele ser vista como un enorme pescado o bien 
como un remolino. Otras exégesis dan cuenta de una Sirena monstruosa, con la cabeza de un peligroso reptil dentado (Lazcarro 2009: 5).

En su carácter de proveedora es benévola, aunque sumamente voluble, por lo que los otomíes acuden a estos sitios a dejarle ofrendas: "Una canasta con comida, bebida, artículos femeninos como espejos, zapatillas blancas, vestidos (verde-azul o blanco), abanicos, sombrillas, lápiz labial, sostenes, collares, aretes, anillos y jabones, para que pueda bañarse" (Lazcarro 2009: 7). Esta sirena también aparece en los manantiales bajo la forma de una mujer seductora que atrae a los hombres al agua, una vez ahí los ahoga, los absorbe en un remolino, para tomarlos como peones. Tiene, en el proceso sincrético con el catolicismo, una advocación, la de San Juanita, pareja de San Juan. A esta sirena se la celebra el 3 de mayo y a San Juan, el 24 de junio. En Zirahuén, aunque ya no se celebra más, la fiesta de san Juan parecía ser una de las fiestas que más entusiasmaba a los zirahuenses. Según Gabino Calvillo y su esposa Esther Ávalos:

Temprano el día de San Juan era un gusto irse a bañar al lago era un gusto, porque de Copándaro, para allá a seis kilómetros, allá se habían tronado el agua. Mire, el agua la tronaban, lo harían con las manos, quién sabe, se oía recio como una tambora el agua. Que le hacían así, se oía el agua pero recio. Quién sabe cómo la harían que sonara. Pero harta gente el día de San Juan a, a bañarse toda la gente. De aquí, de allá de los ranchos, de donde quiera se oía que se bañaban temprano, como a las cinco estaban bañándose en el agua. Porque en la mañana está el agua como un caldo. Calientita, calientita está el agua.

La sirena de Zirahuén no tiene en torno suyo una ritualidad tan explícita, sin embargo presenta ciertas características comunes con la sirena otomí: es voluntariosa en tanto que quita y da pescados y se manifiesta como una mujer seductora que ahoga a los hombres.

Por otra parte, como ya vimos, el lago-mujer también se materializa como un objeto. La jícara se obtiene de una planta que pertenece a la misma familia de la calabaza, las cucurbitáceas. En la cosmovisión mesoamericana las plantas heredan características de la época en la que se cosechan y se inscriben en la misma taxonomía que rige el cosmos. La calabaza y la jícara pertenecen al ámbito de lo femenino y son de naturaleza fría. Según Olivia Kindl, entre los huicholes:

La temporada húmeda, vinculada con la fertilidad de la tierra, el crecimiento de las plantas en general y del maíz en particular, se asocia por lo general con aspectos femeninos. En cambio, en la estación seca los elementos 
predominantes son masculinos y se relacionan con el sol o el fuego. El cultivo de la jícara se ubica entonces en un contexto agrícola que tiene un significado particular en la cosmovisión huichola. Dicho contexto confiere a la jícara un valor simbólico vinculado con las antepasadas femeninas, protectoras de la lluvia y la fertilidad (2003: 54).

El uso de las jícaras como contenedor es anterior al surgimiento de la agricultura, pues al ser tan ligera, permite su fácil transportación. En los relatos recopilados en Zirahuén, la jícara puede ser de oro o estar decorada como las jícaras que venden en Pátzcuaro, es decir, una jícara maqueada ${ }^{17}$.

El uso de la jícara puede inscribirse en dos ámbitos distintos: vida cotidiana y vida ritual. En el contexto ritual la jícara contiene las ofrendas que se le otorgarán a la entidad con la que se quiere establecer contacto. En algunos sitios se utiliza como un instrumento de adivinación. En tiempos prehispánicos también tenía estos usos; los mexicas, por ejemplo, poseían unas vasijas de piedra equiparables a las jícaras en las que entregaban la sangre y el corazón de los sacrificados a los dioses, las quauhxicalli (cf. Kindl 2003: 23). Las jícaras, al igual que otros objetos rituales, son utilizadas como una especie de vaso comunicante con el mundo numinoso.

En el caso que nos ocupa, la jícara es una entidad animada. La jícara se presenta en los discursos de los zirahuenses de forma humanizada: "una jícara bien bonita", "una jícara bien adornadita"; que tiene capacidad de movimiento: "se va metiendo, se va metiendo". Entre los huicholes, por ejemplo, las jícaras rituales no son "ninguna imagen o retrato de otra cosa externa a éstas, sino que las figuras encarnan, es decir, son antepasados deificados o seres humanos [...]. Las jícaras huicholas constituyen de por sí un microcosmos y no una mera imagen ni un retrato del cosmos" (Kindl 2003: 45). Al igual que la sirena que con su hermosura atrae a los hombres, la jícara produce en los que la miran el mismo efecto: despierta el deseo. La jícara es también el lago-mujer, por eso activa en sus víctimas el mismo mecanismo que la sirena. Los ribereños las nombran a ambas como "los encantos del lago" o "los encantos de la sirena”. Su uso podría inscribirse en el ámbito de lo ritual, simbólicamente, al igual que antaño, la jicarita tiene una función votiva: entregar la víctima sacrificial a Zirahuén para calmar su apetito.

\footnotetext{
${ }_{17} \mathrm{El}$ maque es una técnica decorativa de larga tradición prehispánica que consiste en decorar objetos con una mezcla de tierras y aceites provenientes de minerales, vegetales y animales, dependiendo de los colores.
} 


\section{CONCLUSIONES}

Para los zirahuenses son dos las fiestas más importantes: la de la Santa Cruz y la fiesta del Corpus Christi, pues implican gastos mayores e involucran a todos los miembros de la comunidad. Ambas fiestas suceden en el umbral de la estación de lluvias y tienen una carga simbólica asociada con el principio femenino, según la taxonomía mesoamericana. Las fiestas se desarrollan en dos sitios distintos, uno identificado con el ritual católico y otro que incorpora la geografía ritual de los pueblos prehispánicos; en ambas fiestas se trata de un lugar acuático: el cerro como bodega de las aguas y la plazoleta convertida en lago por medio de una danza simbólica. No es casualidad que el mismo día de la fiesta grande en Zirahuén, el 3 de mayo, día de la Santa Cruz, se celebre a la sirena huasteca. Tampoco es casualidad que la fiesta de San Juan fuera celebrada entre los otomíes.

La construcción discursiva del lago de Zirahuén puede inscribirse en la visión del mundo de los pueblos mesoamericanos. Entre los ejemplos que hemos citado, observamos cómo se da una especie de traslape entre espacio y tiempo, entre símbolos y conceptos, entre geografía y persona. De tal manera que la tierra, los cerros, los lagos y toda la paisajística ritual adquieren características humanas: viven, respiran, necesitan comer, tienen necesidades fisiológicas. La madre tierra, por ejemplo, en su advocación de Cihuacóatl se dejaba ver vestida de blanco en el tianguis, y abandonaba una cuna que contenía un pedernal en señal de que tenía hambre y necesitaba ser alimentada con un sacrificio. Estos seres tienen una presencia decisiva en la vida de las comunidades. Se inscriben en alguna de las taxonomías bipartitas de opuestos que se complementan: lo femenino y lo masculino. Si la sirena Xumfø Dehe, tiene a su parte complementaria, su San Juan, el lago-mujer Zirahuén tiene también su complemento, el lago-hombre Pátzcuaro en el que se ahogan "puras mujeres".

Podríamos, especulando, suponer a partir de las fuentes que el lago pudo haber sido un espacio ritual destinado al sacrificio de hombres y mujeres, pues entre los tarascos era una práctica común:

Basalenque [...] nos dice sobre la laguna de Yuririapundaro: "que allí echaban los cuerpos que se sacrificaban a sus dioses”. Esto último se sugiere igualmente para el transgresor Curatame, de quien Tariácuri, su padre, exclamó: “iMuera el bellaco lujurioso! [...] iEchadle a la laguna!" (Relación de Michoacán 1980: 171). Algo semejante se supone debería suceder a Mahuina, la cuñada infiel del mismo Tariácuri: "iPluguiera a los dioses que la tomaran y la sacrificaran sus hermanos y la echaran en el río” (idem: 146147) (González Martínez 2013: 228). 
De ser así, quizás el mismo nombre del lago Zirahuén al estar vinculado con el sustantivo humo, 'sirauta' encierra un carácter simbólico, es una ofrenda votiva que, al igual que la sangre, es alimento para los dioses ${ }^{18}$. No olvidemos que en una de las versiones el lago crece cuando María Helena, la chica que iba por agua con su cántaro, cae en él, convirtiéndose en víctima sacrificial.

Zirahuén y sus formas -paisaje geográfico, sirena y jícara- articulan un complejo cultural alimentado por el pensamiento de los pueblos originarios y adaptado a los procesos históricos vividos por los habitantes ribereños. En la narrativa tradicional sobre el lago-mujer, así como en las fiestas religiosas prevalece simbólicamente el principio femenino. Agua, oscuridad, deseo, fertilidad, vida y muerte dan cohesión a una geografía que sigue teniendo un carácter mítico y que se actualiza en los actos rituales. El narrar o contar relatos sobre el lago-mujer y sus personificaciones, el hacerlo parte de la existencia de los ribereños constituye también un acto de este tipo. La sirena y la jícara son entonces manifestaciones del deseo, de la necesidad del lagomujer de recibir su tributo: su sacrificio ritual.

\section{OBRAS CITADAS}

\section{Referencias bibliográficas}

Alcalá, Jerónimo de (2000). Relación de Michoacán. Coord. Moisés Franco Mendoza. Paleografía: Clotilde Martínez Ibáñez y Carmen Molina Ruiz. México: El Colegio de Michoacán, Gobierno del Estado de Michoacán.

Alcalá, Salvador (2008). "Con devoción llegan los peregrinos ante el Señor del Perdón, en Zirahuén”. El Sol de Morelia. Web. http://www.oem.com.mx/esto/notas/n675265.htm [Último acceso: 03.11.2013].

Catálogo de localidades de la Secretaría de Desarrollo Social, Municipio de Salvador Escalante (2010). Web. http://www.microrregiones.gob.mx/ catloc/LocdeMun.aspx?tipo $=$ clave $\&$ campo $=$ loc\&ent $=16 \&$ mun $=079$.

[Último acceso: 10.01.2014].

${ }^{18}$ La sangre es el alimento de los antepasados, quienes a cambio de esta ofrenda protegen la salud y el sustento de los vivos. En cuanto al humo, se puede interpretar que se asocia con el fuego y el aire. Este último, a su vez, se vincula en la cosmovisión huichola con el aliento vital, o kipuri. Estas diferentes sustancias tienen por denominador común permitir el paso de un nivel del cosmos al otro, en este caso del mundo de los humanos al de los ancestros deificados (Kindl 2003: 154). 
Cortés Máximo, Juan Carlos y Gerardo Baltazar (2010). "El Corpus Christi en un pueblo de la sierra P'urhépecha. Noticia hemerográfica de la fiesta de Paracho, 1902”. TZINTZUN. Revista de Estudios Históricos 52: 179-192.

Cuello, Delia, Arturo Argueta y François Lartigue (1986). La pesca en aguas interiores. México: Cuadernos de la Casa Chata. Centro de Investigaciones y Estudios Superiores en Antropología Social.

Espejel, Carbajal, Claudia (2000). Relación de Michoacán. Instrumentos de Consulta. Web. http://etzakutarakua.colmich.edu.mx/proyectos/ relaciondemichoacan. [Último acceso: 30.01.2014].

Espinosa Isidro, Félix de (1945). Crónica de la Provincia Franciscana de los apóstoles San Pedro y San Pablo de Michoacán. Ed. Nicolás León México: Santiago.

Félix Báez-Jorge (2000). Los oficios de las diosas (Dialéctica de la religiosidad popular en los grupos indios de México). Xalapa: Universidad Veracruzana.

Gilberti, Maturino fray (1997). Vocabulario en lengua de Mechuacan. México: El Colegio de Michoacán, Fideicomiso Teixedor.

González Martínez, Roberto (2013). "Muerte y destinos post mortem entre los tarascos prehispánicos”. Anales de Antropología 47.I: 211-242.

González Torres, Yólotl (2010). "Sexualidad y religión”. Arqueología Mexicana XVIII.104: 70-75.

Kindl, Olivia (2003). La jícara huichola. Un microcosmos mesoamericano. México: CONACULTA, INAH.

Lazcarrro, Israel (2009). "Pueblos Indígenas de México y Agua: Otomíes de la Huasteca”. Atlas de culturas del agua en América Latina y el Caribe. México: UNESCO. Web. http://www.unesco.org.uy/phi/aguaycultura/ en/inicio/atlas-de-las-culturas-hidricas.html [Último acceso: 07.09. 2013].

López Austin, Alfredo (1983). "Nota sobre la fusión y la fisión de los dioses en el panteón mexica”. Anales de Antropología 20, t. II: 75-87.

—. (2010). "La sexualidad en la tradición mesoamericana". Arqueología Mexicana XVIII. 104: 70-75.

—. (2013). "Sobre el concepto de cosmovisión". Debate sobre el concepto de cosmovisión. Taller Signos de Mesoamérica. Web. http://www.iia.unam.mx/difusion/2013/185/TallerSignosdeMesoamrica [Último acceso: 18.12.2013]. 
—. y Leonardo López Luján (2009). Monte Sagrado-Templo Mayor. El cerro y la pirámide en la tradición religiosa mesoamericana. México: IIA-UNAM, INAH.

López Hernández, Miriam (2012). Mujer divina, mujer terrena. Modelos femeninos en el mundo mexica y maya. México: Libros de Araucaria.

Monzón, Cristina (2005). "Los principales dioses tarascos: un ensayo de análisis etimológico en la cosmología tarasca”. Relaciones 104. XXVI: 136-168.

Morante López, Rubén B. (2000). "El universo mesoamericano. Conceptos integradores". Desacatos. Revista de Antropología Social 5: 31-44.

Moreno, Juan José (1776). "Descripción del Obispado de Michoacán”. Paleografía: Carlos Paredes. Fondo Mexicano de la Biblioteca Nacional de Francia. Web. http://www.amoxcalli.org.mx/paleografia.php?id=321 [Último acceso: 12.12.2013].

Neff Nuixa, Françoise (2008). "Los caminos del aire. Las idas y venidas de los meteoros en La Montaña de Guerrero” en Annmária Lammel, Marina Goloubinoff y Esther Katz, eds. Aires y lluvias. Antropología del clima en México. México: CIESAS, CEMCA, Institut de Recherche pour le Développement. 323-341.

Ramírez Barreto Ana Cristina (2010). “Eréndiras de leyenda y carne y hueso”. Relaciones XXXI: 85-118.

Ramírez, Francisco, S.J. (1959). "Relación sobre la residencia de Michoacán (Pátzcuaro)”. Monumenta Mexicana, II (1581-1585), Doc. 173, Roma.

Ruiz, Eduardo (1900) Michoacán: paisajes, tradiciones y leyendas. Vol. II. México: Secretaría de Fomento.

Sahagún, Bernardino fray de (2006). Historia general de las cosas de la Nueva España. México: Porrúa.

Starr, Frederick (1908). In Indian Mexico. A Narrative of Travel and Labor. Chicago: Chicago Forbes and Company. Web. http://www. gutenberg.org/files/16183/16183-h/16183-h.htm. [Último acceso: 05.11. 2013].

Taube, Karl A. (2009). "Itzam Cab Ain: Caimanes, cosmología y calendario en el Yucatán del período Postclásico. Traducción de "Itzam Cab Ain: Caimans, Cosmology, and Calendrics in Postclassic Yucatán.” Research Reports on Ancient Maya Writing 26. 1989. Center for Maya Research. Web. http://www.mesoweb.com/bearc/cmr/RRAMW26es.pdf. [Último acceso: 11.11.2013]. 
Tena, Rafael (paleografía y trad.) (2011). Mitos e historias de los antiguos nahuas. México: CONACULTA.

Torquemada, Juan de (1975). Monarquía Indiana. Vol. III. Libro sexto, México: Universidad Nacional Autónoma de México.

Vázquez, Gabriel et al. (2010). "Registro sedimentario de los últimos ca. 17000 años del lago de Zirahuén, Michoacán, México”. Boletín de la Sociedad Geológica Mexicana 62.3: 325-343.

Velázquez, Primo Feliciano (1992). Códice Chimalpopoca: Anales de Cuauhtitlan y Leyenda de Los Soles. México: UNAM.

\section{Entrevistas}

Fernando Calvillo, 47 años, pescador. Entrevista realizada el 17.06. 2013.

Gabino Calvillo, 82 años, anunciador de noticias y eventos por megáfono. Entrevista realizada el 18.06. 2013.

Juan Melchor, 35 años, pescador. Entrevista realizada el 25.01.2013.

María de la Salud Melchor Villa, 12 años, estudiante. Entrevista realizada el 25.01.2013.

María Teresa Melchor Moya, 72 años, artesana. Entrevista realizada el 25.01. 2013.

Salud Padilla Saucedo, 68 años, comerciante. Entrevista realizada el 26.01.2013.

Guillermina Patricio Moncada, 54 años, artesana. Entrevista realizada el 26.05.2013.

Eliodoro Sanabria, 70 años, pescador. Entrevista realizada el 26.05.2013. 